\author{
Armen Checzojan, Jewgienij Gurinow \\ Fundacja Rozwoju i Wspierania Studiów Armenologicznych „Aniw” \\ MiŃSK-ERYWAŃ-MOSKWA
}

\title{
FUNDACJA ROZWOJU I WSPIERANIA STUDIÓW ARMENOLOGICZNYCH „ANIW” \\ PRZEGLĄD DZIAŁALNOŚCI
}

\begin{abstract}
Abstrakt: Fundacja Rozwoju i Wspierania Studiów Ormiańskich „Aniw” została oficjalnie zarejestrowana w 2015 roku w Moskwie oraz w 2019 roku w Erewaniu. Wcześniej jej założyciele (osoby prywatne) realizowali indywidualnie różne projekty związane z tematyką ormiańską. Misją fundacji jest wspieranie interesów Armenii i Ormian poprzez badania naukowe, projekty kulturalne i publiczne. Główne kierunki działalności to: organizowanie i prowadzenie badań naukowych nad historią i kulturą Armenii; promowanie rozwoju dialogu w dziedzinie studiów ormiańskich (armenologii), nawiązywanie i rozwijanie kontaktów między ormiańskimi naukowcami z różnych krajów świata; zachowanie i popularyzacja historycznego i kulturowego dziedzictwa narodu ormiańskiego; wspieranie badaczy i młodych naukowców zajmujących się badaniami ormiańskimi.
\end{abstract}

Słowa kluczowe: Fundacja Rozwoju i Wspierania Studiów Ormiańskich „Aniw”, armenologia, Ormianie w Rosji, Ormianie na Białorusi.

Fundacja Rozwoju i Wspierania Studiów Armenologicznych „Aniw” została oficjalnie zarejestrowana w 2015 roku w Moskwie, a w 2019 roku w Erywaniu. We wcześniejszym okresie jej założyciele (osoby prywatne) realizowali różne projekty związane z tematyką armenologiczną niezależnie od siebie. Misją fundacji jest wspieranie interesów Armenii i narodu ormiańskiego poprzez badania naukowe, projekty kulturalne i społeczne. Główne kierunki działalności to:

- organizowanie i prowadzenie badań naukowych dotyczących historii i kultury Armenii; 
- popieranie dialogu w zakresie armenologii, nawiązywanie i rozwijanie kontaktów między armenologami z różnych krajów świata;

- zachowanie i popularyzowanie historycznego i kulturowego dziedzictwa narodu ormiańskiego;

- wsparcie badaczy i młodych naukowców zajmujących się badaniami armenistycznymi.

Do tej pory fundacja „Aniw” zrealizowała szereg różnych projektów z zakresu armenologii. W szczególności, wspólnie z partnerami, zorganizowała i przeprowadziła pięć konferencji międzynarodowych w Armenii, na Białorusi i w Rosji. Wzięło w nich udział ponad 200 specjalistów z 23 krajów. Dotychczas ukazały się materiały z dwóch konferencji, pozostałe są w przygotowaniu.

Fundacja „Aniw” realizuje projekt tworzenia ilustrowanych map panoramicznych przedstawiających historyczne i kulturowe dziedzictwo Ormian w różnych regionach świata. Mapy powstają w wyjątkowej technice. Łączy ona panoramiczną mapę krajobrazową z ręcznie rysowanymi wstawkami przedstawiającymi centra historycznych miast lub ilustracje zabytków. Przygotowano i opublikowano mapy centrum historycznego Erywania, mapę Arcachu, trwają prace nad mapą gmin ormiańskich na Krymie. W 2016 roku ukazała się ilustrowana mapa panoramiczna Ormianie na ziemiach Królestwa Polskiego i Wielkiego Księstwa Litewskiego w XIV-XVIII wieku, przygotowana przez czteroosobowy zespół w składzie: Ruben Atojan, Andrzej A. Zięba, Krzysztof Stopka i Armen Checzojan. Pracę sfinansowały fundacja „Aniw” i polskie Ministerstwo Kultury i Dziedzictwa Narodowego. Mapa została wydana w językach ormiańskim, polskim i rosyjskim. Planowana jest także edycja w języku angielskim. Mapa ta powstała w rezultacie wieloletnich prac badawczych, które uzupełniły materiały z kilku wypraw objazdowych przeprowadzonych przez członków fundacji po terytoriach współczesnej Białorusi, Polski i Ukrainy. Przedstawia ona 113 ośrodków związanych z historią i kulturą Ormian, a także liczne obiekty ich dziedzictwa historycznego i kulturowego. Mapa zawiera między innymi ręcznie rysowane wstawki z mapami historycznych centrów miast: Zamościa, Kamieńca Podolskiego, Jazłowca, Lwowa, Warszawy i Krakowa. Mapa była wielokrotnie przedrukowywana; jej fragmenty wykorzystano w szeregu innych publikacji.

Przywiązujemy dużą wagę do utrwalenia pamięci o Ormianach, którzy przyczynili się do zwycięstwa krajów koalicji antyhitlerowskiej podczas drugiej wojny światowej. W 2018 roku fundacja wspólnie z władzami miasta Horodek (Białoruś) odsłoniła pomnik marszałka Iwana Bagramiana. W 2019 roku imię marszałka otrzymała największa szkoła w Witebsku. W tym samym czasie ukazała się monografia Żotnierze Ormianie w bojach o Białoruś (1941-1944)1, przy-

${ }^{1}$ Воинь-армяне в боях за Беларусь (1941-1944 г2.), red. А. Литвин, А. Хечоян, Минск 2019. 
gotowana z inicjatywy i przy bezpośrednim udziale fundacji „Aniw”. Przedstawia dane dotyczące 6500 Ormian, w tym ponad 3000, którzy zginęli na Białorusi. Dzięki publikacji książki nazwiska wielu poległych podczas tej wojny zostały ocalone od zapomnienia. Podczas prac nad książką ustalono losy kilkudziesięciu osób, które zaginęły na Białorusi bez wieści².

Za jedno z głównych zadań fundacja uważa tłumaczenie i publikowanie najważniejszych prac naukowych z zakresu armenologii. Opublikowała tłumaczenia na język rosyjski następujących prac: Ludobójstwo Ormian. Petna historia Raymonda Kévorkiana ${ }^{3}$ (z języka francuskiego), Pótnocny Arcach Samwela Karapetiana $^{4}$, a także zbiór esejów i artykułów Jurija Barsegowa Ormianie a międzynarodowy handel morski $i^{5}$ (z języka ormiańskiego). Zostały też zakończone prace nad rosyjskim thumaczeniem monografii Wyrok $w$ Stambule. Procesy sądowe w sprawie ludobójstwa Ormian autorstwa Vahakna Dadriana i Tanera Akçama ${ }^{6}$; skład jest już gotowy i niebawem trafi do druku.

W celu popularyzacji dziedzictwa historyczno-kulturowego Armenii odbywają się także koncerty, prezentacje książek i wykłady publiczne. Pracownicy fundacji corocznie biorą udział w kilku konferencjach naukowych, na których prezentują efekty swej działalności.

Kilka lat przed oficjalną rejestracją fundacji grono osób ją organizujących, wespół z Narodowym Muzeum Sztuki Republiki Białorusi i przy wsparciu Ministerstwa Spraw Zagranicznych, Ministerstwa Kultury Republiki Białorusi, Ministerstwa Kultury i Dziedzictwa Narodowego Rzeczypospolitej Polskiej oraz Instytutu Polskiego w Mińsku, przygotowało konferencję „Kultura artystyczna gmin ormiańskich na ziemiach Rzeczypospolitej” (9-11 października 2012). Nie będzie przesadą stwierdzenie, że była to pierwsza konferencja ormiańska na Białorusi. Wzięło w niej udział 29 prelegentów z Armenii, Białorusi, Litwy, Polski, Rosji, Ukrainy i Francji. Zajmowano się przede wszystkim źródłami historyczny-

${ }^{2} \mathrm{Z}$ historią jednego z tych żołnierzy można się zapoznać w artykule Galiny Ulitionok: Г. Улитёнок, Могилу юного Ерджаника Бадаляна удалось отыскать в Городокском районе спустя 75 лет, „Беларусь сегодня”, 30 października 2018, https://www.sb.by/artic les/my-vse-dolzhny-drug-drugu-pomogat-html.

${ }^{3}$ R. Kévorkian, Le génocide des Arméniens, Paris 2006, przekład rosyjski: Р. Кев во к ян, Геноиид армян. Полная история, tłum. Л. Щукин, Москва 2015.

${ }^{4}$ U. Yupuuliunjuq [S. Karapetian], Zjnıuhuujhq Unguhu [Północny Arcach], Łpluui [Erywań] 2004, przekład rosyjski (uzupełniony o nowe dane): С. Карапетян, Ceверный Apu̧ax, tłum. Д. Григорян, red. А. Арутюнян, Е. Гуринов, Н. Акопов, Москва 2018.

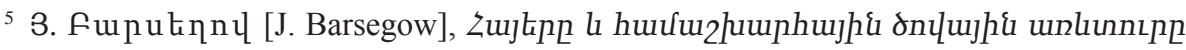
[Ormianie a międzynarodowy handel morski], Gpluui [Erywań] 2018.

${ }^{6}$ V. N. Dadrian, T. A kçam, Judgment at Istanbul. The Armenian Genocide Trials, New York-Oxford 2011, przekład rosyjski: В. Дадрян, Т. Акчам, Приговор в Стамбуле: cyдебные процессы по делу о геноциде армян, thum. Л. Овсепян, red. А. Авагян (w druku). 
mi i literackimi, architekturą, sztuką i rzemiosłem. Materiały z konferencji zostały opublikowane w książce, która ukazała się w następnym roku?

W 2015 roku w Mińsku odbyła się kolejna konferencja naukowa z zakresu armenologii - „Ormiańsko-białoruskie stosunki historyczne i kulturowe. Tradycje i współczesność” (21-22 maja), zorganizowana wspólnie przez fundację „Aniw”, Instytut Historii Narodowej Akademii Nauk Białorusi i Instytut Historii Narodowej Akademii Nauk Republiki Armenii. Dzięki konsekwentnym staraniom fundacji o zacieśnienie kontaktów między armenologami z różnych krajów znacznie wzrosła liczba uczestników konferencji (47 prelegentów z Armenii, Białorusi, Belgii, Litwy, Polski, Rosji, Ukrainy i Francji) i rozszerzyły się obszary badawcze. Tematy referatów przedstawionych na konferencji dotyczyły następujących problemów: historyczne kontakty Ormian z narodami Rzeczypospolitej; wspólnoty ormiańskie Białorusi, Polski, Ukrainy i Litwy; dziedzictwo historyczne i kulturowe gmin ormiańskich Rzeczypospolitej; zachowanie i badania naukowe dokumentów i pomników wspólnego dziedzictwa ormiańsko-białorusko-polsko-ukraińskiego. W ramach programu kulturalnego konferencji 22 maja w Państwowej Filharmonii Białoruskiej odbył się koncert zespołu solistów КлассикАвангард „Białoruś - Armenia: spotkania muzyczne”. Specjalnie przygotowany program koncertu zawierał utwory Stanisława Moniuszki, słynnego polskiego kompozytora urodzonego na terenie współczesnej Białorusi (Ubiel), mającego też korzenie ormiańskie. Wygłoszone referaty i materiały konferencyjne zostały opublikowany w książce, która ukazała się w 2019 roku$^{8}$; jej prezentacja miała miejsce w Ambasadzie Republiki Armenii w Republice Białorusi.

We wrześniu 2016 roku w Moskwie odbyła się duża konferencja międzynarodowa zorganizowana wespół z Państwowym Uniwersytetem Moskiewskim imienia Łomonosowa i Wydziałem Historii tegoż uniwersytetu, Instytutem Historii Narodowej Akademii Nauk Republiki Armenii, Instytutem Starych Rękopisów imienia Mesropa Masztoca „Matenadaran” i szeregiem innych organizacji. Wzięło w niej udział ponad 100 prelegentów pochodzących z 14 krajów (między

${ }^{7}$ Художественная культура армянских общин на землях Речи Посполитой: материаль международной научной конференции (Минск, 9-11 октября 2012 г.), red. И. Скворцова, Минск 2013. Zob. też recenzję: О. Алексанян, Художественная культура армянских общин на землях Речи Посполитой: Материаль Международной научной конференции (Минск, 9-11 октября 2012), сост. и отв. ред. И. Н. Скворияова.

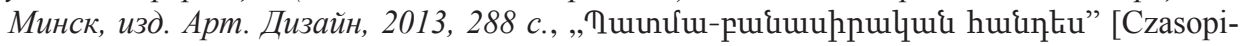
smo Historyczno-Filologiczne], 2014, 1, s. 277-280.

${ }^{8}$ Международная научно-практическая конференция «Армяно-белорусские историко-культурные отношения. Традиции и современность» (Минск, 21-22 мая 2015 г.), red. Е. Гуринов, Москва 2019.

9 Por. А. Соловьянов, Презентация сборника "Международная научнопрактическая конференция „Армяно-белорусские историко-культурные отношения. Традиции и современность”, „Белорусский исторический обзор”, 2019, 1, s. 175-179. 
innymi z Argentyny, Bułgarii, Włoch, Libanu, Polski, USA i Francji). Podczas konferencji omawiano historię diaspory ormiańskiej w Rosji i na świecie, losy historyczne Armenii i Rosji od X do XXI wieku, sztukę ormiańską, problemy źródłoznawcze i historiografię dotyczącą stosunków ormiańsko-rosyjskich.

W 2017 roku, w toku prac nad jednym z projektów, w Narodowym Archiwum Historycznym Białorusi odnaleziono uważaną wcześniej za zaginioną księgę ormiańskiego sądu wójtowsko-ławniczego Zamościa z lat 1660-1668 ${ }^{10}$. By wprowadzić to źródło w obieg naukowy, fundacja „Aniw” pozyskała z archiwum cyfrową kopię tego rękopisu. Przekazano ją następnie zainteresowanym naukowcom z Armenii, Polski i innych krajów.

Udany projekt polskiej Fundacji Kultury i Dziedzictwa Ormian Polskich zainspirował „Aniw” do wydania podobnego ilustrowanego kalendarza poświęconego wybitnym Ormianom. Od 2017 roku wspólnie z ormiańską firmą ArArAt wydaje kalendarz Ormianie na Białorusi. W każdym numerze kalendarza ukazują się biografie i zdjęcia 12 Ormian: naukowców, wojskowych, lekarzy, urzędników, architektów, inżynierów. Niektórzy z nich przez całe życie mieszkali i pracowali na ziemi białoruskiej, inni przyjeżdżali na krótko - do pracy lub w podróży służbowej. Jednakże wszyscy oni zostawili widoczny ślad w historii tego kraju.

W 2018 roku Erywań był gospodarzem międzynarodowej konferencji naukowej pod tytułem „Od krajów bałtyckich do Morza Czarnego. Ormianie w procesach kulturowych, gospodarczych i politycznych" (15-18 października). Organizatorami byli: fundacja „Aniw”, Instytut Historii Narodowej Akademii Nauk Republiki Armenii, Instytut Historii Narodowej Akademii Nauk Białorusi, Polska Akademia Umiejętności (Kraków) i szereg innych organizacji. Konferencja cieszyła się dużym zainteresowaniem specjalistów, było o niej głośno w mediach ${ }^{11}$, ukazały się jej recenzje w publikacjach naukowych ${ }^{12}$. Wzięło w niej udział

${ }^{10}$ Нацыянальны гістарычны архіў Беларусі (Mińsk): f. 1807, op. 1. d. 1. Szczegóły zob. Д. Лисейчиков, Завещания армянских урядников города Замостье середины XVII в. (по материалам Национального исторического архива Беларуси), w: От Балтики до Чёрного моря: армяне в культурных, экономических и политических процессах: материаль международной научной конференции (Ереван, 15-18 октября 2018 г.) (w druku).

${ }^{11}$ Na przykład: N. Boulgourdjian, Conferencia Cientifica Internacional sobre los Armenios en los Procesos Culturales, Económicos y Políticos, „Sardarabad”, 7 listopada 2018,

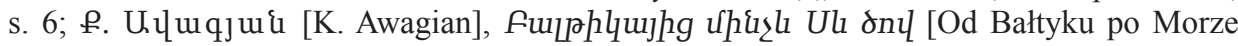
Północne], „Qłunnıpjnı\{” [Nauka], 2018, 11, s. 6-7.

12 Zob. doniesienia na temat konferencji: С. Казаров, Международная научная конференция “От Балтики до Чёрного моря: армяне в культурных, экономических и политических прочессах”. Ереван, 15-18 октября 2018 г., „Новое и прошлое”, 2019, 1, s. 278-284;

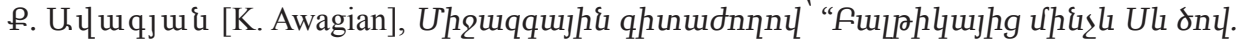

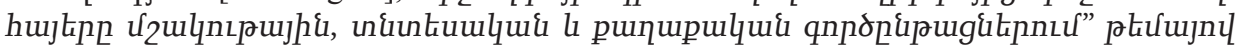
[Międzynarodowa konferencja „Od krajów bałtyckich do Morza Północnego. Ormianie 
64 naukowców z 20 krajów. W ramach konferencji działał osobny panel „Społeczności ormiańskie na terenie współczesnej Białorusi, Polski i Ukrainy. Historia i współczesność". Chociaż w konferencji wzięło udział 4 naukowców z Polski, liczba wystąpień na temat historii Ormian w tamtych stronach i tematów jej pokrewnych była większa i sięgała 14 . Obecnie trwają prace nad przygotowaniem do druku materiałów konferencyjnych.

Fundacja „Aniw” przykłada dużą wagę do rozbudowy sieci kontaktów partnerskich. Do tej pory podpisała umowy ramowe o współpracy z 20 różnymi organizacjami z Armenii, Białorusi, Rosji, Polski; z wieloma z nich realizowane są konkretne projekty naukowe. Fundacja szczególnie ściśle współpracuje z Uniwersytetem Jagiellońskim (Kraków) oraz Fundacją Kultury i Dziedzictwa Ormian Polskich (Warszawa). Włączenie dyrektora generalnego fundacji „Aniw” do Rady Naukowej Ośrodka Badań nad Kulturą Ormiańską w Polsce, otwartego we wrześniu 2019 roku w Polskiej Akademii Umiejętności (Kraków), świadczy o docenieniu jej działań przez polskich naukowców.

Współcześnie fundacja „Aniw” jest organizacją, która dynamicznie się rozwija. Jej działania mają na celu pobudzanie, wspieranie i popularyzację badań naukowych z zakresu armenologii. W jej ,bazie idei” znajduje się ponad 20 obiecujących projektów; nad niektórymi z nich prace już trwają.

Wespół z polskimi badaczami „Aniw” realizuje kilka projektów. Obecnie trwają prace nad przekładem rosyjskim książki Ormiańska Polska ${ }^{13}$. Wydanie rosyjskie zostanie uzupełnione o rozdziały dotyczące historii społeczności ormiańskich w Warszawie, Krakowie i niektórych innych miastach, które nie znalazły się w polskim wydaniu (na ten temat zostały już wydane osobne książki ${ }^{14}$ lub takie są planowane). Wydanie rosyjskiego tłumaczenia książki Ormiańska Polska umożliwi zapoznanie czytelników w Armenii, Rosji, na Białorusi i w innych krajach z ciekawą i bogatą historią polskich Ormian. Rozważamy również możliwość wydania książki w języku ormiańskim. Dla poznania życia Ormian poza krajem ojczystym byłoby bardzo dobrze w przyszłości podjąć podobne badania nad wszystkimi ormiańskimi diasporami na świecie. Pod tym względem książka Ormiańska Polska może służyć za pewien wzór.

Oprócz tego trwają prace nad przygotowaniem do druku publikacji poświęconej kościelnemu ormiańskiemu bankowi Mons Pius, założonemu we Lwowie w 1640 roku i istniejącemu do 1940 roku. W studium autorstwa Andrzeja A. Zię-

w procesach kulturowych, ekonomicznych i politycznych”], „Tuunưu-puiquuhpuulqui huułntu" [Czasopismo Historyczno-Filologiczne], 2018, 3, s. 311-318.

${ }_{13}$ K. Stopka, A. A. Zięba, Ormiańska Polska, Warszawa 2018.

14 Już w 2012 roku opublikowana była książka poświęcona Ormianom warszawskim: K. Stopka, A. A. Zięba, A. Artwich, M. Agopsowicz, Ormiańska Warszawa, Warszawa 2012. 
by opublikowane zostaną dokumenty archiwalne (w języku łacińskim i staropolskim oraz ich tłumaczenia na język rosyjski), a także inne materiały.

W 2020 roku fundacja „Aniw” wraz z Narodowym Archiwum Historycznym Białorusi w Mińsku rozpoczęła prace nad monografią Madżarscy. Ormiańska rodzina $w$ historii Białorusi. Znajdą się tam takie zagadnienia jak historia persjarni słuckiej, genealogia ormiańskiej rodziny Madżarskich i jej związki z okoliczną szlachtą Rzeczypospolitej. W osobnym dodatku znajdą się najważniejsze dokumenty (i ich tłumaczenia) pochodzące z zasobów Narodowego Archiwum Historycznego Białorusi, a także z archiwów polskich i ukraińskich.

Należy podkreślić, że fundacja „Aniw” jest otwarta na współpracę i wyraża gotowość do podjęcia wszelkich interesujących propozycji.

\section{Z języka rosyjskiego przetożyt Krzysztof Stopka}

\section{Bibliografia}

\section{Archiwalia}

Нацыянальны гістарычны архіў Беларусі (Mińsk): f. 1807, op. 1. d. 1, księga ormiańskiego sądu wójtowsko-ławniczego Zamościa z lat 1660-1668

\section{Opracownia}

[Aleksanian O.] Алексанян О., Художественная культура армянских общин на землях Речи Посполитой: Материаль Международной научной конференции (Минск, 9-11 октября 2012), сост. и отв. ред. И. Н. Сквориова. Минск, изд. Арт. Дизайн, 2013, 288 c., „Tuunưu-puquuuhpulqui huiqntu”" [Czasopismo Historyczno-Filologiczne], 2014, 1, 277-280

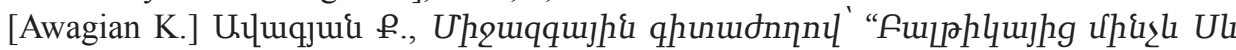

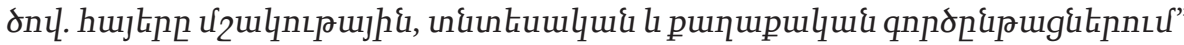
plưujnul [Międzynarodowa konferencja „Od krajów bałtyckich do Morza Północnego. Ormianie w procesach kulturowych, ekonomicznych i politycznych"], "Tuunufu-puiumuppulqui huintiu" [Czasopismo Historyczno-Filologiczne], 2018, 3, s. 311-318

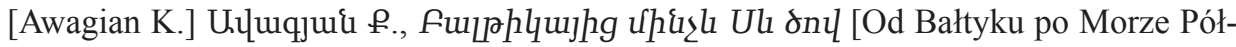
nocne], „, Yhunnıpjnı\{” [Nauka], 2018, 11, s. 6-7

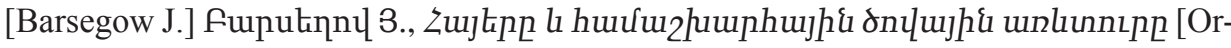
mianie i światowy handel morski], Epluuí 2018

Boulgourdjian N., Conferencia Científica Internacional sobre los Armenios en los Procesos Culturales, Económicos y Políticos, „Sardarabad”, 7 listopada 2018, s. 6

[Chudożestwiennaja] Художественная культура армянских общин на землях Речи Посполитой: материалы международной научной конференции (Минск, 9-11 октября 2012 г.), red. И. Скворцова, Минск 2013

Dadrian V. N., Akçam T., Judgment at Istanbul. The Armenian Genocide Trials, New York-Oxford 2011; przekład rosyjski: Дадрян В., Акчам Т., Приговор в Стамбуле. Судебные проиессы по делу о геноциде армян, tłum. Л. Овсепян, red. А. Авагян (w druku) 
[Karapetian S.], Yupuuutunjuid U., Zjnıuhuu]h\{ Ungußu [Północny Arcach], Epluui [Erywań] 2004; przekład rosyjski (uzupełniony o nowe dane): С.амвел Карапетян, Северный Арцах, tłum. Д. Григорян, red. А. Арутюнян, Е. Гуринов, Н. Акопов, Москва 2018

[Kazarow S.] Казаров С., Международная научная конференция “От Балтики до Чёрного моря: армяне в культурных, экономических и политических процессах”. Ереван, 15-18 октября 2018 г., „Новое и прошлое”, 2019, 1, s. 278-284

Kévorkian R., Le génocide des Arméniens, Paris 2006; przekład rosyjski: Р. Кеворкян, Геноиид армян. Полная история, tłum. Л. Щукин, Москва 2015

[Lisiejczykow D.] Лисейчиков Д., Завещания армянских урядников города Замостье середины XVII в. (по материалам Начионального исторического архива Беларуси), w: От Балтики до Чёрного моря: армяне в культурных, экономических и политических процессах»: материаль международной научной конференции (Ереван, 15-18 октября 2018 г. (w druku)

[Mieżdunarodnaja] Международная научно-практическая конференция «Армянобелорусские историко-культурные отношения. Традиции и современность» (Минск, 21-22 мая 2015 г.), red. Е. Гуринов, Москва 2019

[Sołowjanow A.] Соловьянов А., Презентация сборника "Международная научнопрактическая конференция “Армяно-белорусские историко-культурные отношения. Традиции и современность ”, „Белорусский исторический обзор”, 2019 , 1, s. 175-179

Stopka K., Zięba A. A., Ormiańska Polska, Warszawa 2018

Stopka K., Zięba A. A., Artwich A., Agopsowicz M., Ormiańska Warszawa, Warszawa 2012

[Ulitionok G.] Улитёнок Г., Могилу юного Ерджаника Бадаляна удалось отыскать в Городокском районе спустя 75 лет, „Беларусь сегодня” 30 października 2018, https://www.sb.by/articles/my-vse-dolzhny-drug-drugu-pomogat-.html

[Woiny-armjanie] Воины-армяне в боях за Беларусь (1941-1944 гг.), red. А. Литвин, А. Хечояна, Минск 2019.

\section{Armen Khechoyan, Yevgeny Gurinov, Foundation for the Development and Sup- port of Armenian Studies “Aniv": a brief overview of activities}

Summary: The Foundation for the Development and Support of Armenian Studies "Aniv" was officially registered in 2015 in Moscow and in 2019 in Yerevan. Previously, its founders (private persons) individually carried out various projects related to Armenian issues. The mission of the foundation is to support the interests of Armenia and Armenians through academic research, cultural and public projects. The main areas of its activity are: organizing and conducting research on the history and culture of Armenia; promoting the development of dialogue in the field of Armenian studies (armenology), establishing and developing contacts between Armenian academics from different countries of the world; preservation and popularization of the historical and cultural heritage of the Armenian people; supporting researchers and young scientists involved in Armenian research. 
Keywords: Foundation for the Development and Support of Armenian Studies "Aniv", armenology, Armenians in Russia, Armenians in Belarus

\section{Upultis Iutenjuil, Elqpting] Qnıphinu, Zujuqqunuiquis

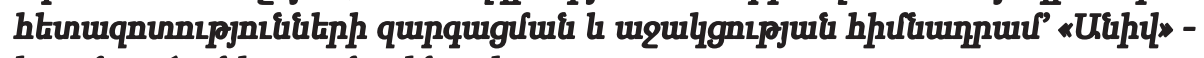 qup}

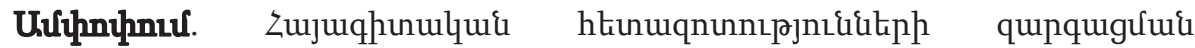

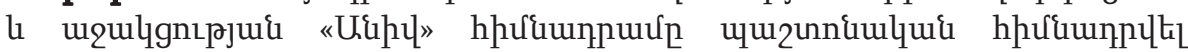

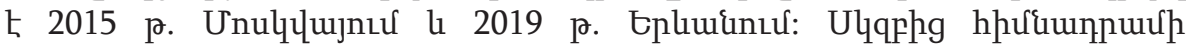

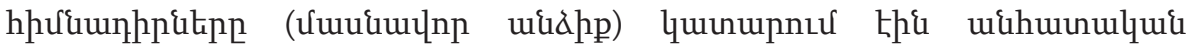

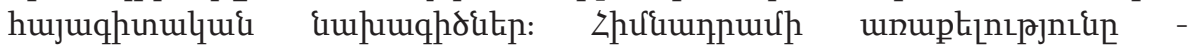

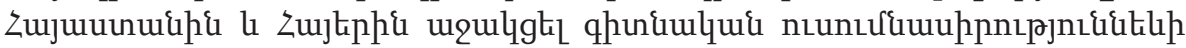

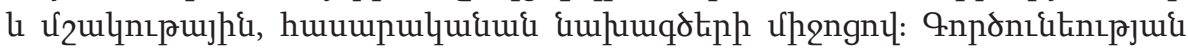

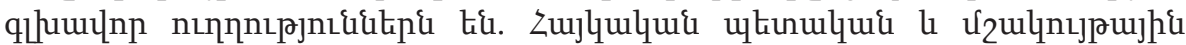

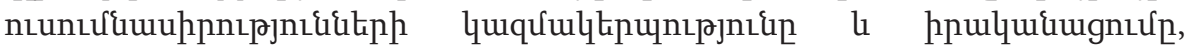

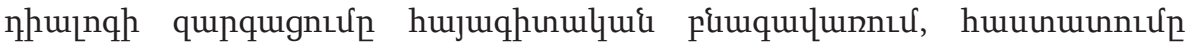

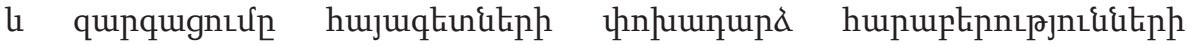

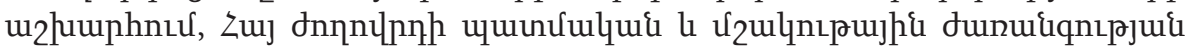

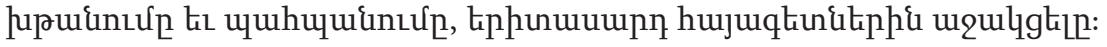

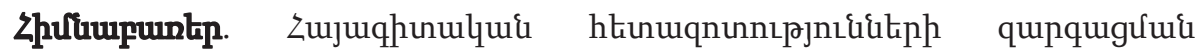

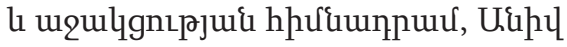

